\title{
Presence and fate of antibiotic residues, antibiotic resistance genes and zoonotic bacteria during biological swine manure treatment
}

\author{
Tina Van den Meersche ${ }^{\mathrm{a}, \mathrm{b}}$, Geertrui Rasschaert ${ }^{\mathrm{a}, *}$, Freddy Haesebrouck $^{\mathrm{b}}$, Els Van Coillie ${ }^{\mathrm{a}}$, \\ Lieve Herman ${ }^{\mathrm{a}}$, Stephanie Van Weyenberg ${ }^{\mathrm{a}}$, Els Daeseleire ${ }^{\mathrm{a}}$, Marc Heyndrickx ${ }^{\mathrm{a}}$, \\ ${ }^{\text {a }}$ Flanders Research Institute for Agriculture, Fisheries and Food (ILVO), Technology and Food Science Unit, Brusselsesteenweg 370,9090 Melle, Belgium \\ ${ }^{\mathrm{b}}$ Ghent University, Department of Pathology, Bacteriology and Avian Diseases, Faculty of Veterinary Medicine, Salisburylaan 133, 9820 Merelbeke, Belgium
}

\section{A R T I C L E I N F O}

\section{Keywords:}

Manure treatment

Antibiotic residues

Antibiotic resistance genes

Salmonella

Campylobacter

E. coli

\begin{abstract}
A B S T R A C T
The presence and dissemination of antibiotic residues, antibiotic resistance genes and zoonotic bacteria in the environment is of growing concern worldwide. Manure management practices, such as biological removal of nitrogen from swine manure, may help to decrease levels of antibiotic residues, antibiotic resistance genes and zoonotic bacteria present in manure before fertilization, thereby reducing environmental contamination. Therefore, the aim of this study was to monitor the presence and fate of seven antibiotic residues (colistin, sulfadiazine, trimethoprim, doxycycline, oxytetracycline, ceftiofur and tylosin A), nine antibiotic resistance genes $(\operatorname{tet}(\mathrm{B}), \operatorname{tet}(\mathrm{L}), \operatorname{tet}(\mathrm{M}), \operatorname{tet}(\mathrm{O}), \operatorname{tet}(\mathrm{Q}), \operatorname{tet}(\mathrm{W}), \operatorname{erm}(\mathrm{B}), \operatorname{erm}(\mathrm{F})$ and sul2) and two zoonotic bacteria (Salmonella Typhimurium and Campylobacter coli) during biological nitrogen removal from swine manure over time. Samples from the raw manure, the solid fraction, the liquid fraction and the storage lagoon were analyzed on two farms at six time points with an interval of two weeks. Only the antibiotics which were used during the three months preceding the first sampling could be detected before and after biological nitrogen removal from swine manure. Of all the antibiotics studied, doxycycline was recovered in all of the samples and sulfadiazine was recovered in most samples on both farms. For both antibiotics, there appears to be a reduction of the amount of residues present in the storage lagoon compared to the liquid fraction, however, this reduction was not statistically significant. A significant reduction of the relative abundances of most of the antibiotic resistance genes studied was observed when comparing the liquid fraction and the storage lagoon. For tet(L), no differences were observed between the fractions sampled and for sul2 and erm(F), a significant increase in relative abundances was observed on the second farm sampled. For the zoonotic bacteria, a reduction of at least 1 log was observed after biological nitrogen removal from swine manure. The results indicate that the concentration of certain antibiotic residues and several antibiotic resistance genes and the amount of zoonotic bacteria present in the manure may be reduced in the end product of the biological nitrogen removal from swine manure.
\end{abstract}

\section{Introduction}

In Flanders (the northern part of Belgium), a total of $126.7 \mathrm{kt}$ of nitrogen $(\mathrm{N})$ from animal manure was produced in 2016. This manure is mostly used to fertilize grasslands and maize, and to a lesser extent for vegetables (Vlaamse Landmaatschappij, 2017). So far, the guidelines for the use of manure have been based on the limitation of the environmental input of nitrates (The Nitrates Directive ND-91/676/EEC) (European Commission, 1991). To reduce the leaching of nitrates by overfertilization, a part of the manure is treated. Besides the northern part of Belgium, other countries such as the Netherlands, France, Germany, etc. also treat part of the produced manure. In Europe, $6.4 \%$ of the total manure production was treated through anaerobic digestion in 2010, making this the most used technique. Treatment of the liquid fraction, as occurs during biological removal of nitrogen from manure, accounted for $0.7 \%$ of the total livestock production in Europe (Foged et al., 2011). As Flanders is listed as a Nitrate Vulnerable Zone (NVZ), this region in Belgium struggles with a significant $\mathrm{N}$ surplus and therefore biological removal of nitrogen is a typically used system as anaerobic digestion still leaves an effluent with high $\mathrm{N}$ content (Bortone, 2009; European Commission, 2018). In Flanders, a total of $44.1 \mathrm{kt} \mathrm{N}$ was treated in 124 plants and biological removal of nitrogen was the most used technique to process swine manure in 2016 (Vlaams Coördinatiecentrum Mestverwerking, 2017). For the biological removal

\footnotetext{
* Corresponding author.

E-mail address: geertrui.rasschaert@ilvo.vlaanderen.be (G. Rasschaert).
} 
of nitrogen from manure, a process of about 35 days is needed. The raw manure first goes into the centrifuge where it is separated in a solid and a liquid fraction. The solid fraction is mostly composted and/or exported and the liquid fraction undergoes the biological nitrogen removal. This is a process of nitrification and denitrification which can be separated in space or in time. During nitrification, ammonium $\left(\mathrm{NH}_{4}{ }^{+}\right)$ is converted to nitrate $\left(\mathrm{NO}_{3}{ }^{-}\right)$by nitrifying bacteria in the presence of oxygen. During denitrification, denitrifying bacteria use the oxygen attached to the nitrate molecule for respiration, creating nitrogen gas as a byproduct (Bernet and Béline, 2009; Flotats et al., 2011). This nitrogen gas bubbles out of the liquid fraction and the end-product, the effluent, goes to a sedimentation tank for an additional sedimentation step. Finally, the upper liquid layer which can be used as a potassium fertilizer is stored in the lagoon until use. The sludge can be re-used in the process to maintain the bacterial culture in the biological treatment plant. In addition to the nitrogen and phosphorus removal, a large decrease of the greenhouse gas methane was shown when biological treatment is applied compared to the traditional storage of manure before spreading (Bernet and Béline, 2009).

Besides the aforementioned environmental issues related to the use of manure, there is a growing concern about the occurrence and dissemination of antibiotic residues into the environment as they may give rise to the emergence of antibiotic resistance and they may be taken up by crops which can be used for animal or human consumption (Boxall et al., 2006; Dolliver et al., 2007; Kumar et al., 2005a, 2005b). Due to antibiotic administration in intensive pig farming, antibiotic resistance selection and transfer can occur in the gastrointestinal tract of pigs. Antibiotic resistant bacteria are excreted in the feces together with antibiotic residues and may enter the environment upon fertilization where the fecal bacteria are disseminated and may exchange resistance genes with soil bacteria and the antibiotic residues may select for more antibiotic resistant bacteria. It has been reported previously that depending on the antibiotic used, $30-90 \%$ of the administered antibiotics are excreted unchanged in the urine or the feces whereupon they may enter the environment (Kumar et al., 2005a, 2005b; Sarmah et al., 2006). Additionally, there is also concern for the dissemination of zoonotic bacteria when using animal manure to fertilize the arable lands as it may contain pathogenic microorganisms such as Campylobacter spp. and Salmonella spp. of which Campylobacter coli and Salmonella Typhimurium are common species/serotypes found in pigs (Bui et al., 2011; Gebreyes and Altier, 2002). This can especially be a problem when cultivating ready-to-eat crops as it has been reported that some pathogenic bacteria can survive for several months in the environment (Hutchison et al., 2005). In addition, Salmonella Typhimurium was frequently found to be multiresistant in swine isolates and the resistance to the multiple antimicrobials is transferrable as they are located on a plasmid (Gebreyes and Altier, 2002; Sisak et al., 2006). The main risk for human and animal health are resistant pathogenic bacteria but it is becoming clear that commensal bacteria, such as $E$. coli, can act as a reservoir for resistance genes which can in turn be transferred to pathogenic bacteria (Patterson et al., 2007; Sharma et al., 2016). To the best of our knowledge, no data are available on the fate of antibiotic residues and antibiotic resistance genes and little information is available on the fate of zoonotic bacteria during nitrogen removal from swine manure (Riaño and García-González, 2014; Vanotti et al., 2005; Viancelli et al., 2013).

Therefore, the aim of this research was to assess whether biological nitrogen removal from swine manure has an influence on the occurrence and fate of a selection of antibiotic residues, antibiotic resistance genes and zoonotic bacteria.

\section{Materials and methods}

\subsection{Sample collection}

Samples were collected from different stages of the biological nitrogen removal from swine manure at six different time points with a two week interval between two samplings. The sampling was carried out on two different swine farms in the spring of 2016 and the winter of 2017 in Flanders. On both farms, only swine manure produced on the farm itself was used in the manure treatment. This allowed monitoring of the antibiotics used on the respective farms. The pigs on the first farm were treated with doxycycline (DOX), sulfadiazine (SDZ), trimethoprim (TMP) and tylosin (TYL) during the three months preceding the first sampling. On the second farm the same antimicrobials were used, with the exception of tylosin.

At each time point, approximately five liters were collected from the raw manure, the solid fraction, the liquid fraction and the storage lagoon. Upon arrival in the lab, subsamples were taken and stored at $-80^{\circ} \mathrm{C}$ for further analysis of the antibiotic residues and at $4{ }^{\circ} \mathrm{C}$ for DNA-extraction which was carried out within $72 \mathrm{~h}$ after sampling. The bacteriological analysis of the samples was carried out the same day.

\subsection{Quantification of antibiotic residues}

\subsubsection{Reagents and materials}

Acetonitrile (MeCN, LC-MS grade) and formic acid 99\% (FA, ULCMS grade) were purchased from Biosolve B.V. (Valkenswaard, The Netherlands). Ammonium formate and trichloroacetic acid (TCA, analytical grade) were purchased from Sigma-Aldrich (Diegem, Belgium). Ultra-pure water was obtained by a Milli-Q system from Millipore.

The reference standards of ceftiofur, sulfadiazine, tylosin tartrate, roxithromycin (I.S.), trimethoprim, doxycycline hyclate, oxytetracycline hydrochloride, methacycline hydrochloride (I.S.), colistin sulfate and the polymyxin B solution (I.S.) were purchased from Sigma-Aldrich (Diegem, Belgium). Sulfadimethoxine- ${ }^{13} \mathrm{C}_{6}$ (I.S.) and trimethoprim- $\mathrm{d}_{9}$ (I.S.) were purchased from WITEGA Laboratorien Berlin-Adlershof $\mathrm{GmbH}$ (Berlin, Germany) and ceftiofur- $\mathrm{d}_{3}$ hydrochloride (I.S.) was purchased from Toronto Research Chemicals (Toronto, Canada).

Polyvinylidene fluoride (PVDF) filters were purchased from MerckMillipore (Carrigtwohill, Ireland), polypropylene (PP) tubes and PP inserts were procured by Novolab (Geraardsbergen, Belgium) and Grace Alltech associates inc. (Lokeren, Belgium), respectively.

\subsubsection{Liquid chromatography-mass spectrometry}

The liquid chromatographic system consisted of an Acquity UPLC Hclass system (Waters). Separation was achieved on a reversed-phase Kinetex $\mathrm{C}_{18}$ column $(100 \mathrm{~mm} \quad \mathrm{x} \quad 2.1 \mathrm{~mm}$ i.d., $1.7 \mu \mathrm{m})$ with a SecurityGuard Ultra guard cartridge system (Phenomenex). The mass spectrometric equipment consisted of a Xevo TQ-S (Waters) equipped with a Z-spray system. The conditions were described previously by Van den Meersche et al. (2016).

\subsubsection{Sample extraction and quantification}

The concentration of the different antibiotic residues (colistin, sulfadiazine, trimethoprim, doxycycline, oxytetracycline, ceftiofur and tylosin A) in each sample was determined as described previously by Van den Meersche et al. (2016) for the raw manure and the liquid fraction (Van den Meersche et al., 2016). For the solid fraction and the fraction sampled from the storage lagoon, a standard addition was used instead of a matrix-matched calibration curve as these samples were too dissimilar from the raw manure samples used for the calibration curve.

\subsection{Quantification of antibiotic resistance genes}

\subsubsection{DNA-extraction}

The DNA extraction was carried out within $72 \mathrm{~h}$ after arrival in the lab. DNA was extracted from $0.25 \mathrm{~g}$ of each sample using the PowerSoil DNA isolation kit (MoBio, Carlsbad, CA, USA) following the manufacturer's instructions. For the storage lagoon samples, $50 \mathrm{ml}$ of sample was centrifuged and $0.25 \mathrm{~g}$ of the pellet was used in the DNA extraction. DNA quantity and quality were determined with the NanoDrop ${ }^{\circledast}$ ND- 
1000 (Thermo Scientific) and the Quantus ${ }^{\mathrm{TM}}$ fluorometer (Promega).

\subsubsection{Quantitative real-time polymerase chain reaction ( $q P C R$ )}

The abundances of nine antibiotic resistance genes belonging to three different antibiotic classes $(\operatorname{tet}(\mathrm{B}), \operatorname{tet}(\mathrm{L}), \operatorname{tet}(\mathrm{M}), \operatorname{tet}(\mathrm{O}), \operatorname{tet}(\mathrm{Q})$, tet $(\mathrm{W}), \operatorname{erm}(\mathrm{B}), \operatorname{erm}(\mathrm{F})$ and sul2) and the $16 \mathrm{~S}$ rRNA gene were quantified in each sample using qPCR. The studied resistance genes belong to different antibiotic classes and include different mechanisms of resistance. The tetracycline resistance genes can be divided in two categories based on the mechanism of resistance: genes encoding efflux pumps (tet(B) and tet( $(\mathrm{L}))$ and genes encoding for ribosomal protection proteins $(\operatorname{tet}(\mathrm{M}), \operatorname{tet}(\mathrm{O}), \operatorname{tet}(\mathrm{Q})$ and $\operatorname{tet}(\mathrm{W}))$. The efflux pump genes are associated with plasmids and the genes for ribosomal protection proteins are usually found on conjugative transposons, with the exception of tet(O) which has also been associated with plasmids. The genes for ribosomal protection proteins and tet( $\mathrm{L})$ are predominantly present in Gram-positive bacteria, however, they may also be present in Gramnegative genera whereas tet(B) is the most widely distributed efflux pump gene among Gram-negative bacteria (Patterson et al., 2007; Roberts, 2012). All of these tetracycline resistance genes are abundantly found in fecal matter and confer resistance to doxycycline, an antibiotic used on both farms (Aminov et al., 2001; Chopra and Roberts, 2001; Patterson et al., 2007; Peak et al., 2007; Roberts, 2012). Sul2 was selected as a representative for the sulfonamide resistance genes as it is predominant in swine manure (Heuer et al., 2009). Finally, erm(B) and erm(F) were selected for the macrolide resistance genes as they are the most abundant ones and they are commonly associated with swine wastes (Knapp et al., 2010; Patterson et al., 2007). These resistance genes are located on conjugative or nonconjugative transposons and have been linked to tet( $\mathrm{M})$ and $\operatorname{tet}(\mathrm{Q})$, respectively (Roberts et al., 1999). Previously published primers and probes for these resistance genes were BLASTed and aligned with several GenBank sequences to ascertain whether they were located in conserved regions of the respective resistance genes (Table 1). Subsequently, a plasmid (for the $16 \mathrm{~S}$ rRNA gene) (IDT, Coralville, IA, USA) and two gBlock $^{\circledR}$ gene fragments (one for the tetracycline resistance genes and one for the sulfonamide and macrolide resistance genes) (IDT, Coralville, IA, USA) were designed containing the consecutive sequences of interest separated by ATAT and were used as standards for quantification purposes. These gBlock $^{\circledast}$ gene fragments and the plasmid were also used to optimize the concentrations of the primers and probes for the selected resistance genes. All primers and probes were ordered from IDT (IDT, Coralville, IA, USA). An efficiency of $90-110 \%$ and a linearity $\left(\mathrm{R}^{2}\right)$ of at least 0.985 were aimed for. The presence of inhibitory substances in the DNA samples prepared from the different matrices was assessed by analyzing three consecutive 1:10 dilutions of the samples by qPCR and comparing their threshold values. If no inhibitory substances are present, the difference in threshold values between two consecutive dilutions should be the same (between 3.1 and 3.58). These experiments revealed that for the resistance genes a 10-fold dilution (1000-fold for tet(M)) and for the 16S rRNA gene a 100-fold dilution of each DNA extract had to be used in the qPCR to avoid reaction inhibition and/or to fall in the range of the standard curve. qPCR analyses were performed using a LightCycler ${ }^{\circledR} 480$ System (Roche). Total 16 S rRNA gene abundance and the abundances of the two macrolide resistance genes (erm(B) and erm(F)) and the sulfonamide resistance gene (sul2) were quantified using SYBR $^{\oplus}$ Green technology. Each reaction mixture consisted of $12.5 \mu \mathrm{l}$ of SsoAdvanced ${ }^{\mathrm{TM}}$ Universal Inhibitor-Tolerant SYBR ${ }^{\circledast}$ Green Supermix (Bio-Rad, Temse, Belgium), the appropriate concentration of each primer (Table 1), $5 \mu$ l of DNA template and sterile water to create a reaction volume of $25 \mu \mathrm{l}$. For the amplification of the target genes, an activation step of $10 \mathrm{~min}$ at $95^{\circ} \mathrm{C}$ was followed by 30 or 40 cycles (for the $16 \mathrm{~S}$ rRNA gene and the macrolide and sulfonamide resistance genes, respectively) of $15 \mathrm{~s}$ at $95^{\circ} \mathrm{C}$ and $1 \mathrm{~min}$ at $60^{\circ} \mathrm{C}$. The specificity of the reaction products was assessed by melting curve analysis. This was performed by gradually increasing the temperature with $0.1{ }^{\circ} \mathrm{C} / \mathrm{sec}$ to $95^{\circ} \mathrm{C}$, with acquisition of data every $2 \mathrm{~s}$. The abundances of the six tetracycline resistance genes, $\operatorname{tet}(\mathrm{B}), \operatorname{tet}(\mathrm{L}), \operatorname{tet}(\mathrm{M})$, tet $(\mathrm{O})$, tet $(\mathrm{Q})$ and tet $(\mathrm{W})$, were quantified using TaqMan ${ }^{\mathrm{TM}}$ Assays. The primers and $\mathrm{ZEN}^{\mathrm{TM}}$ Double-Quenched Probes are listed in Table 1. DNA template $(5 \mu \mathrm{l})$ was added to the reaction mixture containing the appropriate primers and probe, $12.5 \mu \mathrm{l} \mathrm{TaqMan}{ }^{\circledR}$ Environmental Master Mix 2.0 (Applied Biosystems, Foster City, CA, USA) and sterile water to create a reaction volume of $25 \mu$. The tetracycline resistance genes

Table 1

Reaction conditions and sequences of primers and TaqMan probes.

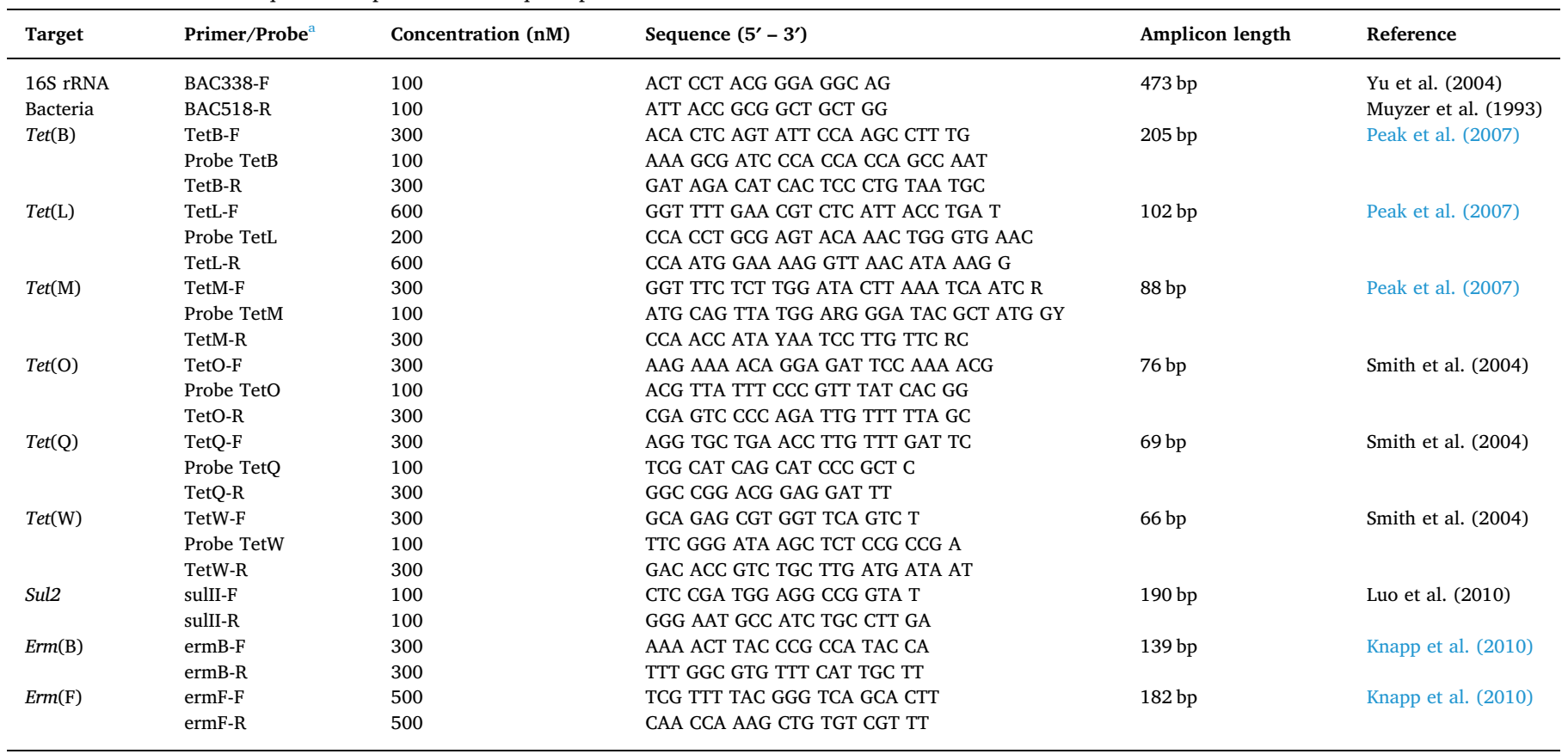

a Probes are tagged with 6-carboxyfluorescein (FAM) at 5', an internal ZEN quencher and an Iowa Black dark quencher (IBFQ) at 3'. 
were amplified by an activation step of $10 \mathrm{~min}$ at $95^{\circ} \mathrm{C}$, followed by 40 cycles of $15 \mathrm{~s}$ at $95^{\circ} \mathrm{C}$ and $1 \mathrm{~min}$ at $60^{\circ} \mathrm{C}$. Within each run, a standard curve was constructed in duplicate using a 10-fold serial dilution of the appropriate plasmid or gBlock $^{\circledast}$ gene fragment (see above), with a range of $10-10^{5}$ gene copy numbers for the resistance genes and $10^{3}-10^{7}$ gene copy numbers for the 16S rRNA gene, for quantification purposes.

The relative abundances of the different antibiotic resistance genes were calculated by dividing the abundance of the respective gene by the $16 \mathrm{~S}$ rRNA gene abundance. This normalization was carried out to account for differences in extraction efficiency and in total bacterial number.

\subsection{Detection of zoonotic bacteria and E.coli}

\subsubsection{Reagents and materials}

Buffered peptone water (BPW) (CM0509), Bolton Broth (CM0983), modified Bolton Broth selective supplement (SR0208E), Ringer solution tablets (BR0052), modified Semi-solid Rappaport Vassiliadis medium Base (MSRV) (CM0910), MSRV selective supplement (SR016E), XyloseLysine-Desoxycholate Agar (XLD) (CM0469), Campylobacter Blood-Free Selective Agar (CCDA) (CM0739) and CCDA selective supplement (SR0155E) were purchased from Oxoid (Basingstoke, UK). RAPID' E.coli 2 agar (356-4024) was purchased from BioRad (Marnes-la-Coquette, France). Defibrinated horse blood (DHB100) was purchased from International Medical products (Oudergem, Belgium).

\subsubsection{Detection of Salmonella}

Detection of Salmonella spp. was carried out according to the ISO 6579-1:2017E protocol with minor modifications (Anonymous, 2017). For the raw manure and the solid fraction samples, $99 \mathrm{ml}$ of BPW were added to $11 \mathrm{~g}$ of sample. For the liquid fraction and the storage lagoon samples, $55 \mathrm{ml}$ of double concentrated BPW were added to $55 \mathrm{~g}$ of sample. After homogenization, three consecutive 1:10 dilutions of the samples were prepared. The samples and the dilutions were then incubated at $37 \pm 1{ }^{\circ} \mathrm{C}$ for $18 \pm 2 \mathrm{~h}$. Subsequently, 3 drops of the preenrichment culture were inoculated on MSRV agar plates supplemented with MSRV selective supplement and incubated at $41.5 \pm 1{ }^{\circ} \mathrm{C}$ for $24 \pm 3 \mathrm{~h}$. Negative plates were incubated for an additional $24 \pm 3 \mathrm{~h}$. From the positive plates, a ten microliter loop from the edge of the migration zone was inoculated on XLD and incubated at $37 \pm 1{ }^{\circ} \mathrm{C}$ for $24 \pm 3 \mathrm{~h}$. Presumptive Salmonella colonies were further confirmed by means of a multiplex Salmonella and Salmonella Typhimurium polymerase chain reaction (PCR) as described by Aabo et al. (1993) and Lin and Tsen (1999), respectively (Aabo et al., 1993; Lin and Tsen, 1999).

\subsubsection{Detection of campylobacter}

For the raw manure and the solid fraction samples, $99 \mathrm{ml}$ of Bolton Broth were added to $11 \mathrm{~g}$ of sample. For the liquid fraction and the storage lagoon samples, $55 \mathrm{ml}$ of double concentrated Bolton Broth were added to $55 \mathrm{~g}$ of sample. After homogenization, three consecutive 1:10 dilutions of the samples were prepared and samples and dilutions were incubated under microaerobic conditions $\left(85 \% \mathrm{~N}_{2}, 10 \% \mathrm{CO}_{2}, 5 \%\right.$ $\mathrm{O}_{2}$ ) in a Forma Series II 3110 Water-Jacketed $\mathrm{CO}_{2}$ incubator (Thermo Scientific, Waltham, MA) at $41.5^{\circ} \mathrm{C}$ for approximately 24 and $48 \mathrm{~h}$. After $24 \mathrm{~h}$ of enrichment, $10 \mu \mathrm{l}$ of the culture was plated on CCDA plates supplemented with CCDA selective supplement (mCCDA). The plates were incubated under microaerobic conditions at $41.5^{\circ} \mathrm{C}$ for approximately 24 and $48 \mathrm{~h}$. If no growth of Campylobacter was observed after $24 \mathrm{~h}, 10 \mu \mathrm{l}$ of the enrichment incubated for $48 \mathrm{~h}$ was plated on mCCDA plates. These plates were also incubated under microaerobic conditions at $41.5^{\circ} \mathrm{C}$ for approximately 24 and $48 \mathrm{~h}$. Colonies of presumptive Campylobacter were confirmed by means of a multiplex Campylobacter jejuni and Campylobacter coli PCR as described previously by Linton et al. (1997).

\subsubsection{Enumeration and detection of E.coli}

For the enumeration of $E$. coli, a 1:10 dilution series of the original samples with BPW was performed in Ringer's solution. Of the original samples and the dilutions, $100 \mu \mathrm{l}$ was plated on RAPID' E. coli 2 plates and incubated at $44^{\circ} \mathrm{C}$ for about $24 \mathrm{~h}$. As for some samples enumeration was not possible, detection of $E$. coli after enrichment was also carried out. Therefore, $10 \mu \mathrm{l}$ of the pre-enriched samples and dilutions with BPW (Section 2.4.2) were plated on RAPID' E. coli 2 plates and incubated at $44^{\circ} \mathrm{C}$ for about $24 \mathrm{~h}$. E. coli can be considered as representative for Gram-negative bacterial species of the commensal microbiota of livestock (Hanon et al., 2015).

\subsection{Statistical analysis of the data}

Normality of the residuals was assessed by means of histograms and Q-Q plots. A log transformation of the data was carried out for the selected resistance genes in order to achieve normality. Linear regression models were fitted with the different antibiotic resistance genes and antibiotic residues $(\operatorname{tet}(\mathrm{B}), \operatorname{tet}(\mathrm{L}), \operatorname{tet}(\mathrm{M}), \operatorname{tet}(\mathrm{O}), \operatorname{tet}(\mathrm{Q}), \operatorname{tet}(\mathrm{W}), \operatorname{ermB}$, ermF, sul2, doxycycline and sulfadiazine) as dependent variables and farm and fraction sampled (raw manure, solid fraction, liquid fraction and storage lagoon) and the interactions between the two variables as independent variables. Statistical significance was considered at P-values $\leq 0.05$. Analyses were performed with $\mathrm{R}$ (version 3.4.1, Vienna, Austria).

\section{Results}

\subsection{Quantification of antibiotic residues}

With regard to the antibiotic residues, only the antibiotics which were used during the three months preceding the first sampling could be detected before and after biological nitrogen removal from swine manure. Oxytetracycline, ceftiofur and colistin were indeed not recovered in any of the samples analyzed. Tylosin was only recovered in two samples on the first farm, once in the raw manure and once in the liquid fraction (data not shown). As mentioned by Van den Meersche et al. (2016), exact quantification could not be carried out for this compound due to high measurement uncertainty but estimates of the concentrations were in the range of $20 \mu \mathrm{gg}^{-1}$ (Van den Meersche et al., 2016). Trimethoprim was found in the solid fraction only on both farms but was almost always present below the limit of quantification (data not shown).

Sulfadiazine and doxycycline were present in the different stages of the biological manure treatment on both farms. The results for the individual farms are presented in Table 2. For both doxycycline and sulfadiazine, the results were somewhat divergent between farm one and farm two which were sampled in spring and in winter, respectively. However, the main trends are similar. For doxycycline, the concentrations on the first farm were ranging from 66.0 to $7744.6 \mu \mathrm{gg}^{-1}, 1058.0-14496.8 \mu \mathrm{g} \mathrm{kg}^{-1}$, $124.6-2540.8 \mu \mathrm{g} \mathrm{kg}^{-1}$ and $13.5-364.6 \mu \mathrm{g} \mathrm{kg}^{-1}$ for the raw manure, the solid fraction, the liquid fraction and the storage lagoon, respectively. For the second farm, they ranged from 103.7 to $963.0 \mu \mathrm{gg}^{-1}$, $2450.4-3500.3 \mu \mathrm{g} \mathrm{kg}^{-1}, 52.6-109.7 \mu \mathrm{g} \mathrm{kg}^{-1}$ and $38.9-299.1 \mu \mathrm{g} \mathrm{kg}^{-1}$, respectively. For sulfadiazine, the ranges for the raw manure, the solid fraction, the liquid fraction and the storage lagoon on the first farm were $\quad 0.0-9.1 \mu \mathrm{g} \mathrm{kg}^{-1}, \quad 55.0-764.1 \mu \mathrm{g} \mathrm{kg}^{-1}, \quad 0.0-10.3 \mu \mathrm{g} \mathrm{kg}^{-1}$ and $<$ $3.5-5.0 \mu \mathrm{gg}^{-1}$, respectively. On the second farm the ranges were $<$ $3.5-67.9 \mu \mathrm{g} \mathrm{kg}^{-1}, \quad 130.0-387.5 \mu \mathrm{g} \mathrm{kg}^{-1}, \quad 12.0-70.7 \mu \mathrm{g} \mathrm{kg}^{-1}$ and $<$ $3.5-15.6 \mu \mathrm{g} \mathrm{kg}^{-1}$, respectively. Statistical analysis of the results indicated a significant difference between the solid fraction and the other fractions sampled ( $<0.001$ ) for both antibiotics. For doxycycline there was also a significant difference between the raw manure and the storage lagoon ( $\mathrm{p}=0.003$ ). However, there was no significant difference between the liquid fraction and the storage lagoon for neither doxycycline nor sulfadiazine. 
Table 2

Overview of the antibiotic residue concentrations and the mean $\left(\mu \mathrm{kg}^{-1}\right)$ for doxycycline (DOX) and sulfadiazine (SDZ) recovered from the different stages of the biological nitrogen removal from swine manure on both farms.

\begin{tabular}{|c|c|c|c|c|c|c|c|c|}
\hline & \multicolumn{4}{|l|}{ Farm 1} & \multicolumn{4}{|l|}{ Farm 2} \\
\hline & Raw manure & Solid fraction & Liquid fraction & Storage lagoon & Raw manure & Solid fraction & Liquid fraction & Storage lagoon \\
\hline \multicolumn{9}{|l|}{ DOX } \\
\hline Time point 1 & 231.1 & 1058 & 139.4 & 37.5 & 945.5 & 3245.7 & 109.7 & 39.5 \\
\hline Time point 2 & 195.6 & 1658.3 & 298.7 & 17.4 & 166.3 & 3379.9 & 88.7 & 46.2 \\
\hline Time point 3 & 7744.6 & $14,496.8$ & 2540.8 & 25.6 & 963.0 & 3197.7 & 67.8 & 38.9 \\
\hline Time point 4 & 327.6 & 1456.6 & 397.9 & 364.6 & 476.2 & 2450.4 & 57.8 & 46.2 \\
\hline Time point 5 & 66.0 & NA & 135.2 & 292.6 & 110.1 & 3500.3 & 55.7 & 299.1 \\
\hline Time point 6 & 196.5 & 2191.1 & 124.6 & 13.5 & 103.7 & 2882.7 & 52.6 & 115.5 \\
\hline Mean & 1460.2 & 4172.2 & 606.1 & 125.2 & 460.8 & 3109.5 & 72.1 & 97.6 \\
\hline \multicolumn{9}{|l|}{ SDZ } \\
\hline Time point 1 & 4.6 & 663.2 & 8.0 & $<\mathrm{LOQ}$ & 67.9 & 387.5 & 70.7 & 15.0 \\
\hline Time point 2 & 8.7 & 55.0 & 8.1 & $<\mathrm{LOQ}$ & 5.2 & 370.4 & 37.0 & 14.6 \\
\hline Time point 3 & 9.1 & 79.0 & 10.3 & $<\mathrm{LOQ}$ & 9.4 & 165.7 & 22.3 & 9.9 \\
\hline Time point 4 & 0.0 & 665.7 & 0.0 & 5.0 & $<\mathrm{LOQ}$ & 148.7 & 16.6 & 9.2 \\
\hline Time point 5 & 0.0 & NA & 0.0 & $<$ LOQ & 8.6 & 142.3 & 14.3 & 15.6 \\
\hline Time point 6 & 4.4 & 764.1 & 0.0 & $<\mathrm{LOQ}$ & 5.6 & 130.0 & 12.0 & $<\mathrm{LOQ}$ \\
\hline Mean & 4.5 & 445.4 & 4.4 & 2.9 & 16.7 & 224.1 & 28.8 & 11.1 \\
\hline
\end{tabular}

NA: Fraction not sampled; < LOQ: Below limit of quantification, LOQ for SDZ is $3.5 \mu \mathrm{g} \mathrm{kg}{ }^{-1}$ There is a two-week interval between the time points.

\subsection{Quantification of antibiotic resistance genes}

Concerning the antibiotic resistance genes, the results are presented in Table 3. For the genes encoding for ribosomal protection proteins, comparable results were obtained with respect to the differences observed between the fractions sampled. The magnitude of the differences observed was different on farm one and farm two which were sampled in spring and winter, respectively. For both farms, a significant reduction of the relative abundance of the selected genes encoding for ribosomal protection proteins with at least $1 \log$ on the first farm and at least $0.5 \log$ on the second farm was observed between the liquid fraction and the storage lagoon (maximum p-value $=0.002$ ), with the exception of $t e t(\mathrm{~W})$ on the second farm for which no significant difference was observed. The mean relative abundance for the different genes encoding for ribosomal protection proteins between the liquid fraction and the storage lagoon on the first farm was reduced with $1.65 \log , 1.24 \log , 1.11 \log$ and $1.30 \log$ for tet( $(\mathrm{M}), \operatorname{tet}(\mathrm{O})$, tet( $(\mathrm{Q})$ and tet (W), respectively. On the second farm the reductions were $0.62 \mathrm{log}$, $0.51 \mathrm{log}, 0.62 \mathrm{log}$ and $0.45 \mathrm{log}$, respectively. As comparable results were obtained for the genes encoding for ribosomal protection proteins, the results for tet $(\mathrm{O})$ are presented in Fig. 1 as an example.

The results for the efflux pump genes were considerably different from the genes encoding for ribosomal protection proteins. For tet $(\mathrm{L})$, a significant difference $(\mathrm{p}<0.001)$ was observed between the two farms but the differences between the samples collected were independent of the farm. This resistance gene did not show any significant difference between the raw manure, the liquid fraction and the storage lagoon. The results observed for tet(B) were divergent for the two farms. On the first farm, which was sampled during spring, a significant reduction $(\mathrm{p}<0.001)$ of the relative abundance of tet(B) with $1.61 \log$ was perceived between the liquid fraction and the storage lagoon. On the second farm, which was sampled during winter, there was no significant difference before and after the manure treatment. These results are presented in Fig. 2.

Sul2 showed contrasting results to the ones described for the tetracycline resistance genes as a significant increase of the relative abundance with $0.50 \log$ was found between the liquid fraction and the storage lagoon $(p=0.025)$ on the second farm. On the first farm, no significant increase nor reduction was observed between these two fractions. For erm(B), significant reductions in relative abundance with $1.58 \log$ and $0.54 \log$ were observed on the first and the second farm, respectively. With regard to erm(F), a significant increase in relative abundance with $0.49 \log$ was observed on the second farm only.
Overall, the relative abundances of the efflux pump genes were about $1 \log$ lower than the relative abundances of the genes encoding for ribosomal protection proteins.

\subsection{Detection of zoonotic bacteria and E.coli}

The results obtained for the zoonotic bacteria and $E$. coli are shown in Table 4 and were different for both farms. On the first farm, which was sampled during spring, the results showed that Salmonella Typhimurium can be present in the different stages preceding the swine manure treatment but it was below the limit of detection in the storage lagoon. Campylobacter coli was recovered from the liquid fraction only. For E. coli, an indicator organism, direct plate counts could only be carried out in the stages preceding the swine manure treatment. For the samples originating from the storage lagoon estimations were made after enrichment, showing a reduction of $E$. coli after swine manure treatment. As estimations had to be made for the storage lagoon samples, the exact reduction between the liquid fraction and the storage lagoon could not be calculated, however, overall the reduction was about $2-3 \log$. On the second farm, which was sampled during winter, Salmonella was not recovered from any of the samples. Campylobacter coli was isolated from all fractions, with the exception of the liquid fraction and overall the total cfu/g was about $1-2 \log$ lower in the storage lagoon compared to the raw manure. Regarding $E$. coli, overall a reduction of about 1-1.5 log was observed after biological nitrogen removal from the liquid fraction of the manure. The reduction was about $2-3 \log$ when the raw manure was compared to the samples from the storage lagoon.

\section{Discussion}

Due to the intensive swine farming and the implementation of the guidelines for the reduction of nitrates in the environment, manure treatment technologies have been increasingly applied. The focus of this study was on the effect of biological nitrogen removal from swine manure on the presence and fate of antibiotic residues, antibiotic resistance genes and zoonotic bacteria (including E. coli as indicator organism) as this is the most used practice in Belgium to treat swine manure (Vlaams Coördinatiecentrum Mestverwerking, 2017).

Concerning the antibiotic residues, to the best of our knowledge, no data are available in literature on their fate during biological nitrogen removal from swine manure. The results presented in this study show that there appears to be a reduction of the amount of antibiotic 
Table 3

The $\log$ (normalized gene abundance of $\operatorname{tet}(\mathrm{B}, \mathrm{L}, \mathrm{M}, \mathrm{O}, \mathrm{Q}$ or $\mathrm{W}) \operatorname{erm}(\mathrm{B}$ or $\mathrm{F})$ or sul2) for the different fractions sampled at the respective time points on both farms is presented. Normalization was carried out by dividing the abundance of the gene of interest by the $16 \mathrm{~S}$ rRNA gene abundance.

\begin{tabular}{|c|c|c|c|c|c|c|c|c|}
\hline & \multicolumn{4}{|l|}{ Farm 1} & \multicolumn{4}{|l|}{ Farm 2} \\
\hline & Raw manure & Solid fraction & Liquid fraction & Storage lagoon & Raw manure & Solid fraction & Liquid fraction & Storage lagoon \\
\hline \multicolumn{9}{|l|}{$\operatorname{Tet}(\mathrm{B})$} \\
\hline Time point 1 & $-3,84$ & $-2,53$ & $-3,79$ & $-5,22$ & $-3,73$ & $-3,04$ & $-3,73$ & $-3,84$ \\
\hline Time point 2 & $-3,44$ & $-2,44$ & $-3,50$ & $-5,30$ & $-3,46$ & $-3,39$ & $-3,86$ & $-4,03$ \\
\hline Time point 3 & $-3,88$ & $-3,01$ & $-3,85$ & $-5,46$ & $-3,37$ & $-3,60$ & $-3,68$ & $-3,98$ \\
\hline Time point 4 & $-3,91$ & $-2,72$ & $-3,86$ & $-5,07$ & $-3,60$ & $-3,36$ & $-3,46$ & $-4,04$ \\
\hline Time point 5 & $-3,49$ & NA & $-3,38$ & $-4,63$ & $-3,58$ & $-3,45$ & $-3,50$ & $-4,08$ \\
\hline Time point 6 & $-4,17$ & $-2,65$ & $-3,51$ & $-5,85$ & $-3,21$ & $-3,74$ & $-3,65$ & $-4,17$ \\
\hline Mean & $-3,79$ & $-2,67$ & $-3,65$ & $-5,26$ & $-3,49$ & $-3,43$ & $-3,65$ & $-4,02$ \\
\hline \multicolumn{9}{|l|}{$\operatorname{Tet}(\mathrm{L})$} \\
\hline Time point 1 & $-3,54$ & $-3,16$ & $-3,57$ & $-3,73$ & $-2,55$ & $-2,10$ & $-2,73$ & $-2,68$ \\
\hline Time point 2 & $-3,94$ & $-4,08$ & $-3,76$ & $-3,72$ & $-2,17$ & $-1,85$ & $-2,71$ & $-2,80$ \\
\hline Time point 3 & $-3,67$ & $-3,40$ & $-3,61$ & $-3,90$ & $-1,96$ & $-1,51$ & $-2,46$ & $-2,66$ \\
\hline Time point 4 & $-3,83$ & $-2,59$ & $-3,84$ & $-4,12$ & $-2,59$ & $-1,73$ & $-2,58$ & $-2,43$ \\
\hline Time point 5 & $-3,91$ & NA & $-3,33$ & $-3,87$ & $-2,63$ & $-2,13$ & $-3,08$ & $-2,96$ \\
\hline Time point 6 & $-3,75$ & $-3,24$ & $-3,36$ & $-4,23$ & $-2,46$ & $-2,43$ & $-2,59$ & $-2,41$ \\
\hline Mean & $-3,78$ & $-3,29$ & $-3,58$ & $-3,93$ & $-2,39$ & $-1,96$ & $-2,69$ & $-2,66$ \\
\hline \multicolumn{9}{|l|}{$\operatorname{Tet}(\mathrm{M})$} \\
\hline Time point 1 & $-0,76$ & $-1,61$ & $-0,76$ & $-2,58$ & $-1,00$ & $-1,41$ & $-1,00$ & $-1,69$ \\
\hline Time point 2 & $-0,96$ & $-1,91$ & $-0,99$ & $-2,57$ & $-1,13$ & $-1,35$ & $-1,12$ & $-1,62$ \\
\hline Time point 3 & $-0,94$ & $-1,10$ & $-0,97$ & $-2,67$ & $-0,99$ & $-1,27$ & $-1,10$ & $-1,64$ \\
\hline Time point 4 & $-0,78$ & $-1,87$ & $-0,84$ & $-2,51$ & $-0,85$ & $-1,10$ & $-0,92$ & $-1,52$ \\
\hline Time point 5 & $-1,05$ & NA & $-1,02$ & $-2,08$ & $-0,89$ & $-1,43$ & $-1,00$ & $-1,89$ \\
\hline Time point 6 & $-0,97$ & $-2,12$ & $-0,91$ & $-2,92$ & $-1,06$ & $-1,49$ & $-1,10$ & $-1,60$ \\
\hline Mean & $-0,91$ & $-1,72$ & $-0,91$ & $-2,56$ & $-0,99$ & $-1,34$ & $-1,04$ & $-1,66$ \\
\hline \multicolumn{9}{|l|}{$\operatorname{Tet}(\mathrm{O})$} \\
\hline Time point 1 & $-2,30$ & $-3,15$ & $-2,30$ & $-3,63$ & $-2,38$ & $-2,77$ & $-2,46$ & $-3,05$ \\
\hline Time point 2 & $-2,57$ & $-3,49$ & $-2,55$ & $-3,64$ & $-2,53$ & $-2,78$ & $-2,51$ & $-3,00$ \\
\hline Time point 3 & $-2,50$ & $-2,65$ & $-2,50$ & $-3,82$ & $-2,52$ & $-2,52$ & $-2,57$ & $-3,04$ \\
\hline Time point 4 & $-2,46$ & $-3,25$ & $-2,46$ & $-3,69$ & $-2,48$ & $-2,53$ & $-2,56$ & $-2,97$ \\
\hline Time point 5 & $-2,75$ & NA & $-2,78$ & $-3,54$ & $-2,53$ & $-2,75$ & $-2,59$ & $-3,33$ \\
\hline Time point 6 & $-2,65$ & $-3,73$ & $-2,57$ & $-4,31$ & $-2,22$ & $-2,74$ & $-2,60$ & $-2,99$ \\
\hline Mean & $-2,54$ & $-3,25$ & $-2,53$ & $-3,77$ & $-2,44$ & $-2,68$ & $-2,55$ & $-3,06$ \\
\hline \multicolumn{9}{|l|}{$\operatorname{Tet}(\mathrm{Q})$} \\
\hline Time point 1 & $-1,92$ & $-3,04$ & $-2,01$ & $-3,82$ & $-2,12$ & $-2,59$ & $-2,14$ & $-2,85$ \\
\hline Time point 2 & $-2,14$ & $-3,14$ & $-2,07$ & $-3,33$ & $-2,19$ & $-2,55$ & $-2,11$ & $-2,80$ \\
\hline Time point 3 & $-2,31$ & $-2,55$ & $-2,24$ & $-3,66$ & $-2,29$ & $-2,46$ & $-2,38$ & $-2,87$ \\
\hline Time point 4 & $-2,19$ & $-3,47$ & $-2,18$ & $-3,04$ & $-2,13$ & $-2,49$ & $-2,27$ & $-2,83$ \\
\hline Time point 5 & $-2,47$ & NA & $-2,35$ & $-2,39$ & $-2,19$ & $-2,67$ & $-2,22$ & $-3,01$ \\
\hline Time point 6 & $-2,25$ & $-3,40$ & $-2,21$ & $-3,42$ & $-2,16$ & $-2,60$ & $-2,26$ & $-2,71$ \\
\hline Mean & $-2,21$ & $-3,12$ & $-2,17$ & $-3,28$ & $-2,18$ & $-2,56$ & $-2,23$ & $-2,85$ \\
\hline \multicolumn{9}{|l|}{$\operatorname{Tet}(\mathrm{W})$} \\
\hline Time point 1 & $-1,88$ & $-2,97$ & $-1,93$ & $-3,22$ & $-1,85$ & $-2,03$ & $-1,94$ & $-2,46$ \\
\hline Time point 2 & $-2,04$ & $-3,19$ & $-2,01$ & $-3,22$ & $-2,00$ & $-2,08$ & $-2,02$ & $-2,40$ \\
\hline Time point 3 & $-2,05$ & $-2,50$ & $-2,08$ & $-3,41$ & $-1,83$ & $-1,92$ & $-1,97$ & $-2,45$ \\
\hline Time point 4 & $-2,01$ & $-3,32$ & $-2,06$ & $-3,27$ & $-2,00$ & $-1,96$ & $-1,99$ & $-2,36$ \\
\hline Time point 5 & $-2,26$ & NA & $-2,15$ & $-3,25$ & $-2,02$ & $-2,26$ & $-2,00$ & $-2,68$ \\
\hline Time point 6 & $-2,35$ & $-3,43$ & $-2,03$ & $-3,66$ & $-1,61$ & $-2,30$ & $-2,07$ & $-2,36$ \\
\hline Mean & $-2,10$ & $-3,08$ & $-2,04$ & $-3,34$ & $-1,89$ & $-2,09$ & $-2,00$ & $-2,45$ \\
\hline $\operatorname{Erm}(\mathrm{B})$ & & & & & & & & \\
\hline Time point 1 & $-1,04$ & $-1,95$ & $-1,13$ & $-2,76$ & $-1,31$ & $-1,59$ & $-1,40$ & $-1,94$ \\
\hline Time point 2 & $-1,00$ & $-1,91$ & $-0,71$ & $-2,81$ & $-1,20$ & $-1,36$ & $-1,39$ & $-1,90$ \\
\hline Time point 3 & $-1,10$ & $-1,27$ & $-0,94$ & $-2,95$ & $-1,17$ & $-1,57$ & $-1,21$ & $-1,82$ \\
\hline Time point 4 & $-1,21$ & $-2,04$ & $-1,04$ & $-2,33$ & $-1,26$ & $-1,52$ & $-1,64$ & $-2,04$ \\
\hline Time point 5 & $-1,11$ & NA & $-1,23$ & $-2,14$ & $-1,15$ & $-1,45$ & $-1,17$ & $-2,03$ \\
\hline Time point 6 & $-1,25$ & $-2,14$ & $-1,09$ & & $-1,34$ & $-1,53$ & $-1,30$ & $-1,63$ \\
\hline Mean & $-1,12$ & $-1,86$ & $-1,02$ & $-2,60$ & $-1,24$ & $-1,50$ & $-1,35$ & $-1,89$ \\
\hline $\operatorname{Erm}(\mathrm{F})$ & & & & & & & & \\
\hline Time point 1 & $-1,16$ & $-1,55$ & $-1,40$ & $-1,26$ & $-1,26$ & $-1,05$ & $-1,42$ & $-1,00$ \\
\hline Time point 2 & $-0,96$ & $-1,64$ & $-0,78$ & $-1,50$ & $-1,00$ & $-0,94$ & $-1,50$ & $-0,96$ \\
\hline Time point 3 & $-1,02$ & $-1,08$ & $-0,81$ & $-1,16$ & $-0,92$ & $-1,48$ & $-1,25$ & $-0,95$ \\
\hline Time point 4 & $-1,35$ & $-1,36$ & $-1,12$ & $-1,12$ & $-1,29$ & $-1,37$ & $-1,79$ & $-1,07$ \\
\hline Time point 5 & $-1,33$ & NA & $-1,07$ & $-0,97$ & $-1,33$ & $-1,26$ & $-1,26$ & $-1,04$ \\
\hline Time point 6 & $-1,04$ & $-1,34$ & $-0,89$ & $-1,12$ & $-1,27$ & $-1,21$ & $-1,40$ & $-0,71$ \\
\hline Mean & $-1,14$ & $-1,39$ & $-1,01$ & $-1,19$ & $-1,18$ & $-1,22$ & $-1,44$ & $-0,95$ \\
\hline Sul2 & & & & & & & & \\
\hline Time point 1 & $-2,24$ & $-0,94$ & $-2,27$ & $-2,03$ & $-1,90$ & $-1,33$ & $-1,93$ & $-1,38$ \\
\hline Time point 2 & $-1,63$ & $-0,57$ & $-1,48$ & $-2,05$ & $-1,63$ & $-1,27$ & $-2,00$ & $-1,39$ \\
\hline Time point 3 & $-1,82$ & $-1,24$ & $-1,93$ & $-2,03$ & $-1,39$ & $-1,87$ & $-1,78$ & $-1,38$ \\
\hline Time point 4 & $-2,31$ & $-0,98$ & $-2,03$ & $-1,47$ & $-2,12$ & $-1,86$ & $-2,41$ & $-1,72$ \\
\hline Time point 5 & $-2,11$ & NA & $-1,74$ & $-1,60$ & $-1,99$ & $-1,59$ & $-1,84$ & $-1,49$ \\
\hline Time point 6 & $-1,80$ & $-0,74$ & $-1,71$ & $-1,94$ & $-1,75$ & $-1,49$ & $-2,00$ & $-1,61$ \\
\hline Mean & $-1,99$ & $-0,89$ & $-1,86$ & $-1,85$ & $-1,80$ & $-1,57$ & $-1,99$ & $-1,49$ \\
\hline
\end{tabular}




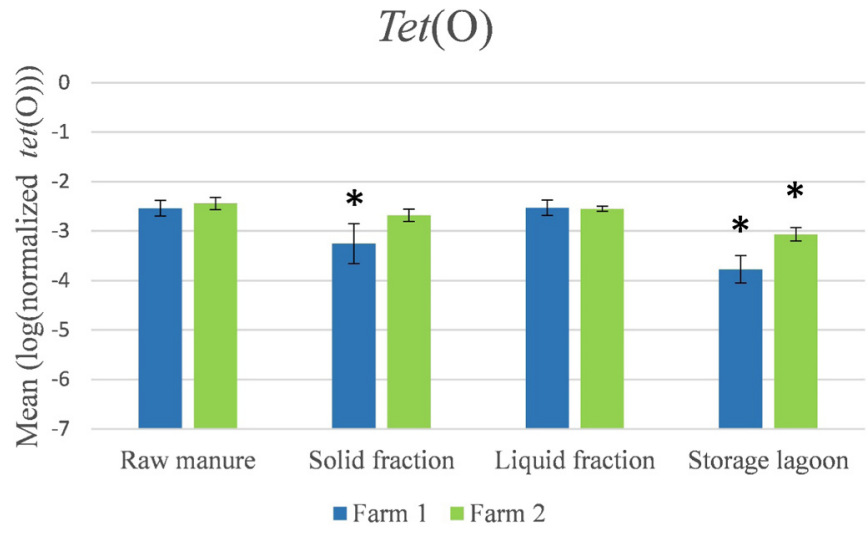

Fig. 1. The mean $(\log ($ normalized gene abundance of tet $(\mathrm{O})))$ is presented for the different fractions sampled on both farms. The results for the other genes encoding for ribosomal protection proteins are analogous. *: significantly different from the other fractions sampled.

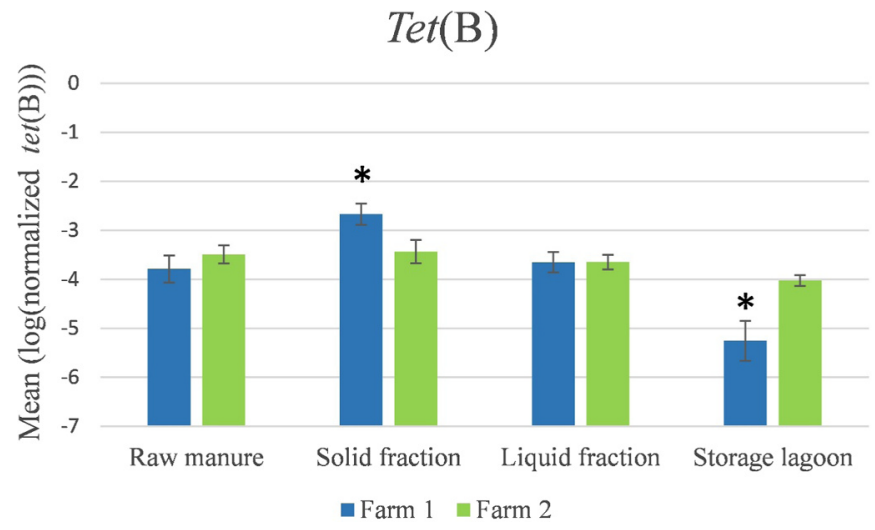

Fig. 2. The mean $(\log ($ normalized gene abundance of tet(B)) ) is presented for the different fractions sampled on both farms. *: significantly different from the other fractions sampled.

residues present in the storage lagoon compared to the liquid fraction, however, this reduction was not statistically significant. This is probably due to the high variation between the data points and the limited amount of data points available for statistical analysis (Table 2). Therefore, additional data are needed to confirm these findings. Statistical analysis does however show that biological nitrogen removal from swine manure may indeed be a tool to reduce the amount of certain antibiotic residues present in the swine manure as a significant reduction was observed between the raw manure and the storage lagoon for doxycycline. For the tetracyclines and sulfonamides, biodegradation in the aqueous phase or on the surface of particles as well as hydrolysis and photolysis have been reported as important removal pathways (Sharma et al., 2016). Half-lives of antibiotics have also been shown to be lower in water matrices as compared to soil or manure especially in the presence of light due to photochemical transformation (Schmitt et al., 2017). For sulfadiazine, half-lives of about $32 \mathrm{~h}$ and up to 30 days have been reported in water and in manure, respectively (Schmitt et al., 2017; Sukul et al., 2008). For doxycycline, no information on half-lives in water are available and half-lives in manure range from 52 to 100 days (Schmitt et al., 2017). In addition, it has also previously been reported that ultraviolet (UV) light enables the breakdown of antibiotic residues (Keen and Linden, 2013; Yuan et al., 2011). In the present study, the reduction of antibiotic residues was more pronounced on the first farm which was sampled during spring. The UV dose used during the experiments described by the authors above was much higher than the one from sunlight exposure of the lagoon. However, the UV treatments are very limited in time whereas the storage lagoon is subjected to sunlight for long periods of time. Further research on the effect of long-term exposure to sunlight or low UV doses are needed to assess this hypothesis. A change in temperature might also explain the reductions seen, as the reductions are more pronounced on the first farm, which was sampled in spring, compared to the second farm, which was sampled during winter. As there is less bacterial activity during winter there might be less biodegradation of these antibiotic residues by microorganisms (Hu et al., 2010; Sharma et al., 2016). It is therefore useful to take samples for a longer period of time, including the summer and therefore higher temperatures and prolonged sunlight exposure, or until the effluent is used as a fertilizer to be able to confirm these preliminary findings. With regard to the solid fraction, an enrichment of the antibiotic residues was observed. This enrichment is due to the fact that this fraction has a dry matter content which is ten times higher than in the other fractions collected (data not shown), thereby increasing the adsorption of the antibiotic residues to organic compounds or bivalent cations (Schmitt et al., 2017; Teixidó et al., 2012). As in Flanders this solid fraction is mostly exported after composting, which is not always carried out at the same location as the biological removal of nitrogen from swine manure as it is not part of the same process, this practice could not be further investigated during the present study. However, previously published studies showed that composting reduced the concentration of antibiotic residues present in swine manure (Kim et al., 2012; Selvam et al., 2012b; Wu et al., 2011). In the study conducted by Selvam et al. (2012), chlortetracycline and sulfadiazine were removed after 21 days and 3 days, respectively. With regard to ciprofloxacin, $17-31 \%$ of the antibiotic remained in the composting pile (Selvam et al., 2012b). Kim et al. (2012), showed that the decrease in extractable concentration of chlortetracycline, sulfamethazine and tylosin were of $96 \%, 99 \%$ and $95 \%$, respectively (Kim et al., 2012). In another study conducted by Wu et al. (2011), chlortetracycline, oxytetracycline and tetracycline were degraded by 74\%, 92\% and 70\%, respectively (Wu et al., 2011).

For the antibiotic resistance genes, no previously published data on their fate during biological removal of nitrogen from swine manure are available in literature. As mentioned in the results section, the relative abundances of the efflux pump gene levels were lower than the relative abundances of the ribosomal protection protein gene levels. This result was expected as Gram-positive bacteria with a low $\mathrm{G}+\mathrm{C} \%$ content are the most abundant species in the gut and genes encoding for ribosomal protection proteins are of Gram-positive origin with a low $\mathrm{G}+\mathrm{C} \%$ content (Patterson et al., 2007). Of all of the genes encoding for ribosomal protection proteins studied, tet(M) was the most abundant in all of the samples. This result is in line with the fact that this resistance gene can be present in both Gram-positive and Gram-negative bacteria and it was the most commonly detected resistance gene among bacteria studied this far (Roberts, 2005). The reductions of the relative abundances of the antibiotic resistance genes were less pronounced on the second farm compared to the first one and this was especially true for tet(B) for which no significant reduction could be shown on the second farm. This could be due to the time of sampling (winter vs. spring) as previous studies have already shown that sunlight tends to create extreme water-quality conditions with elevated $\mathrm{pH}$ and supersaturated oxygen, which suggests that light-associated factors may influence antibiotic resistance gene degradation rate. This was observed previously for tetracycline resistance genes by Engemann et al. (2006). Peak et al. (2007) also observed that resistance gene levels are highly seasonal in wastewater lagoons with concentrations being 10-100 times greater in the autumn compared to the summer (Peak et al., 2007). With regard to the significant increase in relative abundance of erm(F) on the second farm, Tien et al. (2017) reported that this resistance gene was significantly more abundant in anaerobically digested dairy manure than in the raw manure (Tien et al., 2017). This could be due to the fact that some microorganisms are enriched during waste treatment (Tien et al., 2017). In light of the results from the present study, this suggests that some resistance genes might be more abundant after treatment of the 
Table 4

Detection of Salmonella Typhimurium (Salm.) and Campylobacter coli (C. coli) and enumeration of E. coli (cfu/g) in the different fractions sampled.

\begin{tabular}{|c|c|c|c|c|c|c|c|c|c|c|c|c|}
\hline \multirow[b]{2}{*}{ Farm 1} & \multicolumn{3}{|c|}{ Raw manure } & \multicolumn{3}{|c|}{ Solid fraction } & \multicolumn{3}{|c|}{ Liquid fraction } & \multicolumn{3}{|c|}{ Storage lagoon } \\
\hline & Salm. & C. coli & E.coli & Salm. & C. coli & E.coli & Salm. & C. coli & E.coli & Salm. & C. coli & E.coli \\
\hline 1 & $10-10^{2 \mathrm{a}}$ & - & $1,2.10^{4}$ & $1-10^{\mathrm{a}}$ & - & $9,8 \cdot 10^{3}$ & $2-20^{\mathrm{a}}$ & - & $5,7.10^{3}$ & - & - & $0,2-2^{\mathrm{a}}$ \\
\hline 2 & $10-10^{2 \mathrm{a}}$ & - & $5,5.10^{3}$ & $1-10^{\mathrm{a}}$ & - & $5,7.10^{4}$ & $20-200^{\mathrm{a}}$ & $20-200^{\mathrm{a}}$ & $1,1.10^{4}$ & - & - & $0,2-2^{\mathrm{a}}$ \\
\hline 3 & $1-10^{\mathrm{a}}$ & - & $8,5.10^{4}$ & - & - & $8,7.10^{4}$ & $0,2-2^{\mathrm{a}}$ & $20-200^{\mathrm{a}}$ & $1,2.10^{5}$ & - & - & $0,02-0,2$ \\
\hline 4 & - & - & $7,0.10^{3}$ & - & - & $4,0.10^{2}$ & $0,2-2^{\mathrm{a}}$ & $20-200^{\mathrm{a}}$ & $5,8 \cdot 10^{3}$ & - & - & $0,2-2^{\mathrm{a}}$ \\
\hline 5 & - & - & $1,0.10^{2}$ & - & - & NA & $0,2-2^{\mathrm{a}}$ & - & $2,0.10^{2}$ & - & - & $20-200^{\mathrm{a}}$ \\
\hline 6 & $0,1-1^{\mathrm{a}}$ & - & $10^{2}-10^{3 a}$ & - & - & $6,2.10^{3}$ & - & $2-20^{\mathrm{a}}$ & $6,4.10^{2}$ & - & - & $2-20^{\mathrm{a}}$ \\
\hline 1 & - & $10^{2}-10^{3 \mathrm{a}}$ & $6,2.10^{4}$ & - & $10^{2}-10^{3 \mathrm{a}}$ & $6,8.10^{4}$ & - & - & $2,1.10^{4}$ & - & $0,2-2^{\mathrm{a}}$ & $2,0.10^{2}$ \\
\hline 2 & - & $10^{2}-10^{3 \mathrm{a}}$ & $1,9.10^{5}$ & - & - & $6,4.10^{4}$ & - & - & $7,6.10^{3}$ & - & - & $2,2.10^{2}$ \\
\hline 3 & - & $10-10^{2 \mathrm{a}}$ & $4,1.10^{5}$ & - & $10-10^{2 \mathrm{a}}$ & $2,6.10^{4}$ & - & - & $2,3.10^{3}$ & - & $0,2-2^{\mathrm{a}}$ & $3,8.10^{2}$ \\
\hline 4 & - & $10-10^{2 \mathrm{a}}$ & $7,0.10^{2}$ & - & - & $2,6.10^{4}$ & - & - & $3,1.10^{3}$ & - & - & $20-200^{\mathrm{a}}$ \\
\hline 5 & - & $10^{2}-10^{3 \mathrm{a}}$ & $4,3 \cdot 10^{3}$ & - & $10^{2}-10^{3 \mathrm{a}}$ & $5,5.10^{4}$ & - & - & $6,8 \cdot 10^{2}$ & - & $2-20^{\mathrm{a}}$ & $2,6.10^{2}$ \\
\hline 6 & - & - & $1,4.10^{5}$ & - & - & $3,0.10^{3}$ & - & - & $6,4.10^{2}$ & - & - & $2,6.10^{2}$ \\
\hline
\end{tabular}

Numbers 1-6: sampling time points with a two-week interval between the time points.

NA: Fraction not sampled.

a Estimation after enrichment of dilution series.

manure. As varying results were obtained for the resistance genes studied, the results from the present study cannot be extrapolated to other resistance genes without further research. However, biological swine manure treatment caused a reduction of the relative abundance of most of the antibiotic resistance genes studied, indicating the potential of this type of treatment for the reduction of antibiotic resistance genes present in swine manure. Concerning the solid fraction, previously published studies have reported that antibiotic resistance gene concentrations were reduced after composting of the solid fraction (Selvam et al., 2012a; Wang et al., 2012). In the first study, tet(Q), tet (W), tet (C), tet (G), tet (Z), tet (Y), sul1, sul2, dfrA1, dfrA7, gyrA and parC were reduced to below the limit of detection (Selvam et al., 2012a). The second studied showed a decrease of erm(A), erm(C), erm(F), erm(T), erm(X), tet $(\mathrm{G}), \operatorname{tet}(\mathrm{M}), \operatorname{tet}(\mathrm{O}), \operatorname{tet}(\mathrm{T})$ and $\operatorname{tet}(\mathrm{W})$ of 4 and $7 \mathrm{log}$ for the erythromycinand the tetracycline-resistant bacteria, respectively. This indicates that composting of this fraction, as occurs in Belgium prior to export, is a potential way for reducing the level of antibiotic resistance genes. This practice was however not investigated during the present study as it is not part of the biological removal of nitrogen from swine manure and it was not carried out on either of the farms under investigation.

Regarding the zoonotic bacteria, we may hypothesize that a reduction of the studied zoonotic bacteria occurs as we observed a reduction to below the limit of detection of the studied zoonotic bacteria on the first farm and a partial reduction on the second farm. Furthermore, a reduction of 1-3 log after biological nitrogen removal from swine manure was observed for $E$. coli, which supports our hypothesis. Previous studies have also shown a decrease during biological removal of nitrogen from swine manure for Salmonella (Riaño and García-González, 2014; Vanotti et al., 2005; Viancelli et al., 2013). With regard to Campylobacter coli, the presence of oxygen during the aerobic phase might explain the reduction as these are microaerophilic bacteria (Payot et al., 2004). There might also be competition for resources as the biological removal of nitrogen from manure is carried out by nitrifying and denitrifying bacteria. In addition, environmental factors such as temperature and sunlight might explain the reduction seen for these zoonotic bacteria (Riaño and García-González, 2014). The results presented in the present study indicate that swine manure treatment can be a tool to reduce the zoonotic bacteria present in the swine manure.

The results presented in this study indicate that the use of effluent as a potassium fertilizer will have a lower impact on the environment as compared to the use of raw manure when comparable amounts are used on the arable land as a reduction was observed for the antibiotic residues, most of the antibiotic resistance genes and for the zoonotic bacteria. However, the antibiotic residue concentrations present in the effluent may still cause resistance selection as it has been shown that concentrations up to 100 -fold below the minimal inhibitory concentration of the susceptible wild-type strain can still select for resistant bacteria and the epidemiological cutoff value for doxycycline is between $0.5 \mathrm{mg} / \mathrm{L}$ and $8 \mathrm{mg} / \mathrm{L}$ depending on the bacterial species (Andersson and Hughes, 2014; EUCAST, 2018; Jechalke et al., 2014). The use of effluent may also promote the dissemination of antibiotic resistance genes as these are still present in this type of matrix and reinfection with zoonotic bacteria is not excluded as these might also be present after biological removal of nitrogen from swine manure, although the levels are lower than in the raw manure. Furthermore, in Flanders, approximately twice as much effluent may be used per ha compared to raw manure and the effluent will most likely be used in combination with manure fertilization and will not replace it as the effluent is a potassium fertilizer and does not contain enough nitrogen for plant growth. This implies that the practice of biological manure treatment in order to alleviate the $\mathrm{N}$ surplus may inadvertently increase the dissemination of antibiotic residues, antibiotic resistance genes and zoonotic bacteria into the environment if the effluent is used in combination with raw manure. As no data are available on the actual usage of effluent, it is difficult to assess the true burden of this practice on the environment. In addition, the amount of manure which can be applied is determined by guidelines which may differ depending on the region. However, we attempted to carry out an evaluation of some possible scenarios using the mean doxycycline concentration over both farms as an example.

In the first scenario, raw manure is used without the addition of any other fertilizer. This practice is carried out by farmers with no excess of manure. In this case, antibiotic residues, antibiotic resistance genes and zoonotic pathogens may be disseminated in the environment upon fertilization if these emerging pollutants are present in the raw manure. The results obtained in the present study indicate that high concentrations of doxycycline and high relative abundances of most of the antibiotic resistance genes studied may be present in the swine manure. Salmonella Typhimurium and Campylobacter coli can also be present in high numbers. When using doxycycline as an example this means that $38.0 \mathrm{~g} \mathrm{ha}^{-1}$ will end up on the arable land. The calculation was made by using the mean doxycycline concentration $\left(960.5 \mu \mathrm{g} \mathrm{kg}^{-1}\right)$ and the maximal dose of pig manure which may be applied (39.5 t ha'1) as Flanders is a NVZ. In regions which are not listed as NVZ, higher amounts of manure may be applied, resulting in the dissemination of higher amounts of these emerging pollutants in the environment.

In a second scenario, the raw manure is used in combination with the effluent. This practice is carried out when farmers choose to treat their surplus of manure by means of the biological removal of $\mathrm{N}$ from 
swine manure. In this case, the burden of both fractions has to be added up. As data on actual application of effluent are not available, a scenario with the maximal application rate of effluent was calculated. For doxycycline this means that $39.0 \mathrm{~g} \mathrm{ha}^{-1}$ will end up on the arable land. This concentration is the sum of the doxycycline residues present in the effluent and in the raw manure. As $50 \mathrm{t}$ of effluent have already been applied, the application of raw manure is restricted to $150 \mathrm{~kg} \mathrm{~N}^{-1}$. For the effluent, the concentration of doxycycline is $5.5 \mathrm{~g} \mathrm{ha}^{-1}$ and for the raw manure it is $33.5 \mathrm{~g} \mathrm{ha}^{-1}$. This concentration is similar to the previous scenario.

A third scenario is the combination of effluent with a mineral fertilizer. In this scenario, the burden on the environment will be the lowest as only the effluent causes entry of the studied emerging pollutants into the environment. Even if $50 \mathrm{t}$ of effluent are applied, the burden on the environment will still be lower as compared to the use of raw manure alone. As calculated above, $5.5 \mathrm{~g} \mathrm{ha}^{-1}$ of doxycycline will end up on the arable land. In terms of the studied emerging pollutants, this scenario is the most optimal. However, this last practice is not always feasible in Flanders as this is a region with high manure surplus and the biological removal of $\mathrm{N}$ from swine manure is expensive. In addition, mineral fertilizers would have to be purchased in order to ensure enough nutrients for plant growth, adding up to the costs.

In conclusion, further studies are needed to verify whether the reduction of certain antibiotic residues, several antibiotic resistance genes and the studied zoonotic bacteria is caused by the manure processing, by environmental factors or a combination of both. This will allow farmers to use the effluent during periods when the amount of antibiotic residues, antibiotic resistance genes and zoonotic bacteria is low, especially when the effluent is used to fertilize vegetables which are consumed raw.

\section{Acknowledgements}

This research was funded by a Ph.D. Grant (IWT-SB/141290) of the Agency for Innovation by Science and Technology in Flanders (IWT).

\section{References}

Aabo, S., Rasmussen, O.F., Rossen, L., Sorensen, P.D., Olsen, J.E., 1993. Salmonella identification by the polymerase chain-reaction. Mol. Cell. Probes 7, 171-178. https://doi.org/10.1006/mcpr.1993.1026.

Aminov, R.I., Garrigues-Jeanjean, N., Mackie, R.I., 2001. Molecular ecology of tetracycline resistance: development and validation of primers for detection of tetracycline resistance genes encoding ribosomal protection proteins. Appl. Environ. Microbiol. 67, 22-32. https://doi.org/10.1128/AEM.67.1.22-32.2001.

Andersson, D.I., Hughes, D., 2014. Microbiological effects of sublethal levels of antibiotics. Nat. Rev. Microbiol. 12, 465-478. https://doi.org/10.1038/nrmicro3270.

Anonymous, 2017. International standard 6579-1. Microbiology of the food chain Horizontal method for the detection, enumeration and serotyping of Salmonella. Part 1: Detection of Salmonella spp.

Bernet, N., Béline, F., 2009. Challenges and innovations on biological treatment of livestock effluents. Bioresour. Technol. 100, 5431-5436. https://doi.org/10.1016/j. biortech.2009.02.003.

Bortone, G., 2009. Integrated anaerobic/aerobic biological treatment for intensive swine production. Bioresour. Technol. 100, 5424-5430. https://doi.org/10.1016/j. biortech.2008.12.005.

Boxall, A.B.A., Johnson, P., Smith, E.J., Sinclair, C.J., Stutt, E., Levy, L.S., 2006. Uptake of veterinary medicines from soils into plants. J. Agric. Food Chem. 54, 2288-2297. https://doi.org/10.1021/jf053041t.

Bui, X.T., Wolff, A., Madsen, M., Bang, D.D., 2011. Fate and survival of Campylobacter coli in swine manure at various temperatures. Front. Microbiol. 2, 1-8. https://doi.org/ 10.3389/fmicb.2011.00262.

Chopra, I., Roberts, M., 2001. Tetracycline antibiotics: mode of action, applications, molecular biology, and epidemiology of bacterial resistance. Microbiol Mol. Biol. Rev. 65, 232-260. https://doi.org/10.1128/MMBR.65.2.232-260.2001.

Dolliver, H., Kumar, K., Gupta, S., 2007. Sulfamethazine uptake by plants from manureamended soil. J. Environ. Qual. 36, 1224-1230. https://doi.org/10.2134/jeq.2006. 0266.

Engemann, C.A., Adams, L., Knapp, C.W., Graham, D.W., 2006. Disappearance of oxytetracycline resistance genes in aquatic systems. FEMS Microbiol. Lett. 263, 176-182. https://doi.org/10.1111/j.1574-6968.2006.00419.x.

EUCAST, 2018. Antimicrobial Wild Type Distributions of Microorganisms [WWW Document]. URL $\langle$ https://mic.eucast.org/Eucast2/ $>$ (Accessed 7 October 2018).

European Commission, 2018. Report From the Commission To the Council and the
European on the implementation of counsil directive 91/676/EEC concenrning the protection of waters against pollution caused by nitrates from agricultural sources based on member state reports for the peri 1-13.

European Commission, 1991. Council directive of 12 december 1991 concerning the protection of waters against pollution caused by nitrates from agricultural sources. Off. J. Eur. Communities 1-8.

Flotats, X., Foged, H.L., Bonmatí Blasi, A., Palatsi, J., Magrí, A., Schelde, K.M., 2011. Manure processing technologies. Technical Report No. II concerning Manure Processing Activities in Europe to the European Comission, Directorate-General Environment.

Foged, H.L., Flotats, X., Bonmatí Blasi, A., Palatsi, J., Magri, A., Schelde, K.M., 2011. Inventory of Manure Processing Activities in Europe. Technical Report no. I concerning "Manure Processing Activities in Europe" to the European Commission. Directorate-General Environment.

Gebreyes, W.A., Altier, C., 2002. Molecular Characterization of Multidrug-Resistant Salmonella enterica subsp. enterica Serovar Typhimurium Isolates from Swine. J. Clin. Microbiol. 40, 2813-2822. https://doi.org/10.1128/JCM.40.8.2813.

Hanon, J.-B., Jaspers, S., Butaye, P., Wattiau, P., Méroc, E., Aerts, M., Imberechts, H., Vermeersch, K., Van der Stede, Y., 2015. A trend analysis of antimicrobial resistance in commensal Escherichia coli from several livestock species in Belgium (2011-2014). Prev. Vet. Med. 122, 443-452. https://doi.org/10.1016/j.prevetmed.2015.09.001.

Heuer, H., Kopmann, C., Binh, C.T.T., Top, E.M., Smalla, K., 2009. Spreading antibiotic resistance through spread manure: characteristics of a novel plasmid type with low \%G + C content. Environ. Microbiol 11, 937-949. https://doi.org/10.1111/j.1462 2920.2008.01819.x.

Hu, X., Zhou, Q., Luo, Y., 2010. Occurrence and source analysis of typical veterinary antibiotics in manure, soil, vegetables and groundwater from organic vegetable bases, northern China. Environ. Pollut. 158, 2992-2998. https://doi.org/10.1016/j. envpol.2010.05.023.

Hutchison, M.L., Walters, L.D., Moore, T., Thomas, D.J.I., Avery, S.M., 2005. Fate of pathogens present in livestock wastes spread onto fescue plots. Appl. Environ. Microbiol. 71, 691-696. https://doi.org/10.1128/AEM.71.2.691-696.2005.

Jechalke, S., Heuer, H., Siemens, J., Amelung, W., Smalla, K., 2014. Fate and effects of veterinary antibiotics in soil. Trends Microbiol. 22, 536-545. https://doi.org/10. 1016/j.tim.2014.05.005.

Keen, O.S., Linden, K.G., 2013. Degradation of antibiotic activity during UV/H2O2 advanced oxidation and photolysis in wastewater effluent. Environ. Sci. Technol. 47, 13020-13030. https://doi.org/10.1021/es402472x.

Kim, K.R., Owens, G., Ok, Y.S., Park, W.K., Lee, D.B., Kwon, S.I., 2012. Decline in extractable antibiotics in manure-based composts during composting. Waste Manag. 32 110-116. https://doi.org/10.1016/j.wasman.2011.07.026.

Knapp, C.W., Zhang, W., Sturm, B.S.M., Graham, D.W., 2010. Differential fate of erythromycin and beta-lactam resistance genes from swine lagoon waste under different aquatic conditions. Environ. Pollut. 158, 1506-1512. https://doi.org/10.1016/j. envpol.2009.12.020.

Kumar, K., C. Gupta, S., Chander, Y., Singh, A.K., 2005a. Antibiotic use in agriculture and its impact on the terrestrial environment. Adv. Agron. https://doi.org/10.1016/ S0065-2113(05)87001-4.

Kumar, K., Gupta, S.C., Baidoo, S.K., Chander, Y., Rosen, C.J., 2005b. Antibiotic uptake by plants from soil fertilized with animal manure. J. Environ. Qual. 34, 2082-2085. https://doi.org/10.2134/jeq.2005.0026.

Lin, J.S., Tsen, H.Y., 1999. Development and use of polymerase chain reaction for the specific detection of Salmonella Typhimurium in stool and food samples. J. Food Prot. 62, 1103-1110.

Linton, D., Lawson, A.J., Owen, R.J., 1997. PCR detection, identification to species level, and fingerprinting of Campylobacter jejuni and Campylobacter coli direct from diarrheic samples. J. Clin. Microbiol. 35, 2568-2572.

Patterson, A.J., Colangeli, R., Spigaglia, P., Scott, K.P., 2007. Distribution of specific tetracycline and erythromycin resistance genes in environmental samples assessed by macroarray detection. Environ. Microbiol. 9, 703-715. https://doi.org/10.1111/j. 1462-2920.2006.01190.x.

Payot, S., Dridi, S., Laroche, M., Federighi, M., Magras, C., 2004. Prevalence and antimicrobial resistance of Campylobacter coli isolated from fattening pigs in France. Vet. Microbiol. 101, 91-99. https://doi.org/10.1016/j.vetmic.2004.03.014.

Peak, N., Knapp, C.W., Yang, R.K., Hanfelt, M.M., Smith, M.S., Aga, D.S., Graham, D.W., 2007. Abundance of six tetracycline resistance genes in wastewater lagoons at cattle feedlots with different antibiotic use strategies [WWW Document]. Environ. Microbiol. https://doi.org/10.1111/j.1462-2920.2006.01123.x.

Riaño, B., García-González, M.C., 2014. On-farm treatment of swine manure based on solid-liquid separation and biological nitrification-denitrification of the liquid fraction. J. Environ. Manag. 132, 87-93. https://doi.org/10.1016/j.jenvman.2013.10. 014.

Roberts, M.C., 2012. Mechanisms of bacterial antibiotic resistance and lessons learned from environmental tetracycline-resistant bacteria. In: Keen, P., Montforts, M. (Eds.), Antimicrobial Resistance in the Environment. Wiley-Blackwell, pp. 93-121.

Roberts, M.C., 2005. Update on acquired tetracycline resistance genes. FEMS Microbiol. Lett. 245, 195-203. https://doi.org/10.1016/j.femsle.2005.02.034.

Roberts, M.C., Sutcliffe, J., Courvalin, P., Jensen, L.B., Rood, J., Seppala, H., 1999. Nomenclature for Macrolide and Macrolide-Lincosamide- Streptogramin B Resistance Determinants. Antimicrob. Agents Chemother. 43, 2823-2830.

Sarmah, A.K., Meyer, M.T., Boxall, A.B.A., 2006. A global perspective on the use, sales, exposure pathways, occurrence, fate and effects of veterinary antibiotics (VAs) in the environment. Chemosphere 65, 725-759. https://doi.org/10.1016/j.chemosphere 2006.03.026.

Schmitt, H., ter Laak, T., Duis, K., 2017. Development and Dissemination of Antibiotic Resistance in the Environment under Environmentally Relevant Concentrations of 
Antibiotics and Its Risk Assessment.

Selvam, A., Xu, D., Zhao, Z., Wong, J.W.C., 2012a. Fate of tetracycline, sulfonamide and fluoroquinolone resistance genes and the changes in bacterial diversity during composting of swine manure. Bioresour. Technol. 126, 383-390. https://doi.org/10. 1016/j.biortech.2012.03.045.

Selvam, A., Zhao, Z., Wong, J.W.C., 2012b. Composting of swine manure spiked with sulfadiazine, chlortetracycline and ciprofloxacin. Bioresour. Technol. 126, 412-417. https://doi.org/10.1016/j.biortech.2011.12.073.

Sharma, V.K., Johnson, N., Cizmas, L., McDonald, T.J., Kim, H., 2016. A review of the influence of treatment strategies on antibiotic resistant bacteria and antibiotic resistance genes. Chemosphere 150, 702-714. https://doi.org/10.1016/j.chemosphere. 2015.12.084.

Sisak, F., Havlickova, H., Hradecka, H., Rychlik, I., Kolackova, I., Karpiskova, R., 2006 Antibiotic resistance of Salmonella spp. isolates from pigs in the Czech Republic. Vet. Med. (Praha) 51, 303-310.

Sukul, P., Lamshöft, M., Zühlke, S., Spiteller, M., 2008. Photolysis of 14C-sulfadiazine in water and manure. Chemosphere 71, 717-725. https://doi.org/10.1016/j. chemosphere.2007.10.045.

Teixidó, M., Granados, M., Prat, M.D., Beltrán, J.L., 2012. Sorption of tetracyclines onto natural soils: data analysis and prediction. Environ. Sci. Pollut. Res. 19, 3087-3095. https://doi.org/10.1007/s11356-012-0954-5.

Tien, Y.C., Li, B., Zhang, T., Scott, A., Murray, R., Sabourin, L., Marti, R., Topp, E., 2017. Impact of dairy manure pre-application treatment on manure composition, soil dynamics of antibiotic resistance genes, and abundance of antibiotic-resistance genes on vegetables at harvest. Sci. Total Environ. 581-582, 32-39. https://doi.org/10.1016/j. scitotenv.2016.12.138.

Van den Meersche, T., Van Pamel, E., Van Poucke, C., Herman, L., Heyndrickx, M.,
Rasschaert, G., Daeseleire, E., 2016. Development, validation and application of an ultra high performance liquid chromatographic-tandem mass spectrometric method for the simultaneous detection and quantification of five different classes of veterinary antibiotics in swine manure. J. Chromatogr. A 1429, 1-10. https://doi.org/10. 1016/j.chroma.2015.12.046.

Vanotti, M.B., Millner, P.D., Hunt, P.G., Ellison, A.Q., 2005. Removal of pathogen and indicator microorganisms from liquid swine manure in multi-step biological and chemical treatment. Bioresour. Technol. 96, 209-214. https://doi.org/10.1016/j. biortech.2004.05.010.

Viancelli, A., Kunz, A., Steinmetz, R.L.R., Kich, J.D., Souza, C.K., Canal, C.W., Coldebella, A., Esteves, P.A., Barardi, C.R.M., 2013. Performance of two swine manure treatment systems on chemical composition and on the reduction of pathogens. Chemosphere 90, 1539-1544. https://doi.org/10.1016/j.chemosphere.2012.08.055.

Vlaams Coördinatiecentrum Mestverwerking, 2017. Operationele stand van zaken mestverwerking in Vlaanderen.

Vlaamse Landmaatschappij, 2017. Mestrapport 2017. Jaarlijks rapport over het mestbeheer in Vlaanderen.

Wang, L., Gutek, A., Grewal, S., Michel, F.C., Yu, Z., 2012. Persistence of resistance to erythromycin and tetracycline in swine manure during simulated composting and lagoon treatments. Lett. Appl. Microbiol. 61, 245-251. https://doi.org/10.1111/lam. 12450.

Wu, X., Wei, Y., Zheng, J., Zhao, X., Zhong, W., 2011. The behavior of tetracyclines and their degradation products during swine manure composting. Bioresour. Technol. 102, 5924-5931. https://doi.org/10.1016/j.biortech.2011.03.007.

Yuan, F., Hu, C., Hu, X., Wei, D., Chen, Y., Qu, J., 2011. Photodegradation and toxicity changes of antibiotics in UV and UV/ $\mathrm{H}_{2} \mathrm{O}_{2}$ process. J. Hazard. Mater. 185, 1256-1263. https://doi.org/10.1016/j.jhazmat.2010.10.040. 